\title{
EXPECTATIONS UNLEASHED:
} WHAT MAY COME FROM THE BIDEN ADMINISTRATION AND THE G7 IN 2021

\begin{abstract}
The article evaluates the first 100 days of the Biden administration and the G7 meeting in June 2021 in the U.K. It concentrates on U.S. foreign policy and hopes for the reintegration of the U.S. in European and global structures. The G7 is also reviewed first from the perspective of Euro-Atlantic-China relations, following with reactions to the G7 pandemic relief efforts, and towards proposed climate change policies. In conclusion, the scenarios of "Westlessness," "Westfulness," and "Westishness" are employed to map out potential trajectories for U.S., EU and global developments.
\end{abstract}

KEYWORDS: U.S. foreign policy, G7, pandemic response, climate change, Westlessness

Newspapers ran with headlines like "Biden Boom" (New York Times), "Can Biden achieve an FDR-style presidency?" (Washington Post), "Biden Chooses Prosperity Over Vengeance" (The Atlantic) that reflect a general expectation of a new era dawning with the election of Joseph R. Biden, Jr. as the $4 \mathrm{G}^{\text {th }}$ President of the United States of America. Initial feelings of relief from the contentious Trump administration were tempered with the reality of impending challenges, especially domestically with the Covid 19 pandemic rampant and the demands of economic recovery for economically struggling Americans. Biden brought a human face to the common and immediate needs of Americans and in the first 100 days understated his pandemic relief plans so that today he can claim over $21.3 \%$ of the population (as of April 11, 2021, over 70 million people) are fully vaccinated, thus already exceeding his promise of 100 million shots by 183 million doses administered in his first 100 days.

As the domestic crises will certainly take precedence in this initial period, and as the Biden administration's approach so far has been one of unity in adversity, this is in stark contrast to the polarizing and confrontational former administration. The president held an interesting meeting with historians like 
Doris Kearns Goodwin, Walter Isaacson, and others in early March at the White House. In these discussions it was reported that Biden asked questions about how much change and at what pace Americans could accept historic systemic changes. Biden is already being compared to paradigm changing presidents like FDR, and whereas at the end of the last administration, when Trump warned of apocalyptic consequences if defeated, there is a sense of hope today moving forward.

\section{BIDEN AND FOREIGN POLICY: THE FIRST 100 DAYS}

America's standing in the world was severely damaged during the Trump administration's withdrawal from major international agreements like the Paris Climate Agreement, the Iran nuclear deal, the Trans-Pacific Partnership, the Intermediate-Range Nuclear Forces Treaty, and the Open Skies Treaty. This credibility gap was clearly evident in the contentious initial meetings in Alaska between Biden's Secretary of State Antony Blinken and National Security Adviser Jake Sullivan on the US side, and the Chinese foreign minister Wang Yi, and China's most senior foreign policy official, Yang Jiechi. This led to some reports of a new US-China Cold War. I will contribute more on specific foreign policy issues later.

It appears the new administration is beginning to address the credibility gap at the international level by renewing and strengthening traditional trans-Atlantic partnerships and taking a stronger stance against strong-man countries and regimes that were at the minimum mollified by Trump (Russia, North Korea, Saudi Arabia), at the expense of valuable alliances with traditional US allies in the international arena. There is clearly a lot of reconstruction work that needs to be done to rebuild trust in the reliability of the U.S. as an international partner.

As mentioned above, the initial exchange between the new U.S. administration and seasoned Chinese officials was not encouraging and very confrontational, with Chinese officials mentioning the "slaughter" of black people in the U.S. in response to U.S. accusations of human right violations of the Muslim Uighur minority (what Blinken described as "genocide"), and the authoritarian suppression of democracy protestors in Hong Kong.

The current administration's challenges with China are complex. As Jonathan Marcus (17 March 2021) put it: "How do you press China on introducing fairer trade practices, on democracy or on human rights, while still hoping to cooperate on tackling climate change and ensuring stability in the Asia-Pacific region? It is going to be all about managing strategic competition". It is clear that the competition and the potential for conflict between the U.S. and China will likely intensify in terms of alliance-building, projected military strength, and economic and political governance models. 
With regard to Russia, again, initial contact with the new Biden administration was tough and confrontational, especially after the newly elected president called Putin a "killer" - to which Russia responded by recalling its ambassador and trumpeting the U.S. legacy of Native American genocide, slavery and the bombing of Hiroshima. Subsequently, representatives from both countries suggested they would try and agree in areas of mutual interest. Most experts agree that the U.S.Russia relationship will remain tense now and in the coming years and they speak of the priority to prevent any military confrontations, including unintended incidents or reciprocal miscalculations, that may occur that would heighten tensions between the U.S. and its allies and Russia (Al Jazeera 2021 March 19).

\section{PANDEMIC ECONOMIC POLICIES}

In addition to the $\$ 1.9$ trillion stimulus package, a $\$ 3$ trillion green/infrastructure plan has been proposed. If successful, besides rescuing vulnerable populations in or on the edge of poverty, the infrastructure plan, like FDR's New Deal, would stimulate the private sector to create new "green" jobs that improve productivity and economic sustainability. The infrastructure plan would be paid for by raising the corporate tax rate from $21 \%$ to $28 \%$ - a percentage that is still below what corporations paid before President Donald Trump's tax cuts in 2017 which was 35\%. The plan called the "Made in America Tax Plan" also wants to increase the minimum tax on U.S. multinational corporations to $21 \%$, and the new Secretary of the Treasury, Janet Yellen, called for a global minimum corporate tax rate of $21 \%$ to hinder offshore holdings in tax havens. The White House estimates this plan would be paid off in 15 years. Of course, Republicans says it goes too far, and some democrats say it does not go far enough to confront the climate crisis.

\section{A VERY DIVIDED SOCIETY REMAINS}

From the outset, the rhetoric of the new administration in domestic affairs emphasized collective action for the public good. The underlying tensions in American society will remain for a long, long time. However, if the most marginalized groups gain access to vaccinations, one part of one problem will begin to be addressed. Besides the pandemic and economic fallout, the situation of migrants at the border is acute and compelling and needs to be addressed in new legislation and humane border policies. It is clear, that in terms of the Biden administration, the role of government, hopefully good government, is due to increase in response to the structural crises the U.S. faces today.

As Erza Klein (2021 April 8) points out in a recent New York Times opinion piece, the Republican Party has essentially collapsed as a potential negotiating partner negating any kind of bi-partisanship hope to mitigate the current crises. That is why Biden is concentrating on implementing policies that are attractive 
and beneficial to everyday Americans on a broader political spectrum (like the $\$ 1,400$ stimulus checks) which includes Republican voters, thereby bypassing the need for any kind of consensus-building between Democrats and Republicans in government.

The underlying strains of racial and economic injustice, juxtaposed on horrific gun violence, can only be met with reforms of judicial, policing and gun policies. The new social movements like BLM highlight abuses, and the results of the ongoing trial of police officer Derek Chauvin in the killing of George Floyd will have national, if not international, repercussions whichever way it goes. The truth is that American society has changed and is still changing. It is no longer represented by a majority of whites of European extraction, thus the efforts to curtail the voting rights in predominantly non-white voting populations as well as in predominantly anti-republican districts. Republicans, who have not won the popular vote in 3 past presidential elections understand that their hold on power requires dis-enfranchizing large sections of the country. Until a transparent and just system replaces the gerrymandered voter districts, and the limitations to access to voting (as in Georgia recently) are eliminated, populism on all sides will flourish. Until a transparent and just system of representation is implemented and obvious at all levels (local, state, national), until the influence of big money and corporations on politics is regulated, and until stakeholders (politicians, the media, corporations) are held accountable, trust in the democratic system in the U.S. will be crippled and jeopardized.

The latest report of the National Intelligence Council (March 2021), part of the U.S. Intelligence Community, entitled "Global Trends 2040. A More Contested World," states that as people gravitate to like-minded groups and make increasing and varied demands on already strained governments, democracies will become more vulnerable. The report continues that this mismatch between government abilities and public expectations could lead to more political volatility and internal conflicts, polarisation and populism with resultant waves of activism and protest. Two future scenarios stand out in the report: "The World Adrift" scenario imagines that market economies will never recover from the Covid pandemic, reflected in increasingly divided societies that exist in an international system that is "directionless, chaotic and volatile" where international rules and institutions are ignored by major stakeholders (national governments, corporations and other actors). Another scenario, "Tragedy and Mobilisation," depicts a world in the midst of global climate catastrophe in the early 2030s with rampant famine and unrest that leads to a new global coalition of social movements to address the crises.

Whatever the future holds, whatever disruptions may occur as a result of internal and external stimuli - especially the challenges of climate-related factors - the role of all international big powers will be determined by how well they are able to mitigate and navigate the waves of continuing crisis and uncertainty. There 
is a fragile but palpable sense in the U.S. today that some current challenges are, at least initially, being effectively addressed (Covid, the economy) by the new administration, but whether this feeling will remain over the administration's tenure is anyone's guess.

\section{THE G7: THE SPIRIT MAY BE WILLING, BUT THE BODY MAY BE WEAK}

I would not go so far as to say that the signing of a new Atlantic Charter is a sign of international realignment. Rather, it symbolically represents a possible new agreement to share the burdens of combating and mitigating current challenges. As was stated, the new Charter would focus on defense, trade, climate change, protecting biodiversity and combating cyber threats. Democracy promotion, which was an integral part of the original Charter was not emphasized, and admittedly although the world has changed substantially since 1941, there was recognition by the British government that "the values the U.K. and U.S. share remain the same." It is not easy to compare recovery from the devastations of WW II with the ravages of the pandemic, but Prime Minister Boris Johnson stated that "while Churchill and Roosevelt faced the question of how to help the world recover following a devastating war, today we have to reckon with a very different but no less intimidating challenge - how to build back better from the coronavirus pandemic." The British government continued: "Just as our countries worked together to rebuild the world following the Second World War, so too will we apply our combined strength to the enormous challenges facing the planet today - from global defense and security to building back better from coronavirus to stopping climate change."

I do not think that this new Charter has the ambitions and vision of 1941 that many believed shaped a new world order and led to the creation of the UN and NATO. It is more specifically focused on boosting trade and travel between the U.K. and the U.S., and the so-called "landmark" technology pact to promote cooperation between U.K. and U.S. tech firms. Success of these initiatives will depend on concrete policies that would be implemented on both sides of the pond. In my opinion, this is predominantly high rhetoric and restatement of shared values. In this case: "The spirit may be willing, but the body may be weak."

\section{THE G7 AND CHINA}

In contrast to the last in-person meeting of the G7 in 2018 where China was not really mentioned, China was a main topic in 2021. China featured prominently in the G7 communique on Sunday, June $13^{\text {th }}$. It accused China of human rights violations, non-market policies, and asked for more transparency from the Chinese on the origins of the COVID-19 pandemic. Security concerns in the region were also raised. Although the G7 leaders tried to project a united front, they did 
not all agree on a joint competitive infrastructure challenge for developing countries as an alternative to China's massive Belt and Road Initiative (which was unveiled as early as 2013). Only some members of the group want to provide hundreds of billions of dollars in aid to counter Chinese overseas investments. In any case, if this actually did become a viable option, it would not stop the already well-advanced Chinese program. What the G7 democracies could bring to the table of foreign investment are "better safeguards to infrastructure projects including transparency, accountability as well as environmental and social standards," said Matthew Goodman (2021 June 14), senior vice president for economics at Washington D.C.-based think tank Center for Strategic and International Studies. Goodman continued: "I think the tone was pretty clear about the concern that these seven large, advanced market economies have about China, its economic coercion, it's non-market policies, its human rights abuses ... and I think that was well telegraphed in the run-up to the summit, so Beijing shouldn't be surprised."

The Chinese government's response to the criticism and possible global investment challenge articulated at the G7 summit was: "The days when global decisions were dictated by a small group of countries are long gone." Is a new economic Cold War on the horizon between the U.S. and China? Many analysts are predicting further confrontation and weaponization of capital markets, and it can be expected that China will retaliate. For example, if companies comply with U.S. sanctions on China, they could be subject to sanctions in China. However, the larger global context must be also recognized, including other confrontational relations like between the U.S. and Russia, as well as the shared global challenges related to climate change, cyber security, and ransomware which reinforces a shared vulnerability of even the largest economies.

\section{G. PANDEMIC RELIEF AT A CROSS-ROADS}

There were many headlines similar to this: "G7 Leaders to Agree Landmark Global Health Declaration" (G7 Research Group 2021 June 12) related to addressing the continued lack of vaccines for developing countries. G7 leaders were expected to sign the Carbis-Bay Declaration on health to ensure that the human and economic devastation of a pandemic like COVID-19 would not happen again. The U.K. even promised to establish a new center to develop vaccines to prevent zoonotic diseases and their transmission from animals to humans. These leaders and representative observers from South Korea, South Africa, Australia and India, the Secretary General of the UN and leaders of international organizations were met by Sir Patrick Vallance and Melinda French Gates who presented their work and the work of experts on the Pandemic Preparedness Partnership. There were many heady statements about the need for cooperation and coordination on the 
present and future vaccine rollouts, but many critics remained skeptical. According to Max Lawson (2021 June 13), Head of Inequality Policy at Oxfam:

This G7 summit will live on in infamy. Faced with the biggest health emergency in a century and a climate catastrophe that is destroying our planet, they have completely failed to meet the challenges of our times. Never in the history of the G7 has there been a bigger gap between their actions and the needs of the world. In the face of these challenges the G7 have chosen to cook the books on vaccines and continue to cook the planet. We don't need to wait for history to judge this summit a colossal failure, it is plain for all to see. Today the G7 leaders have failed to protect millions of people from the deadly threat of COVID-19. They say they want to vaccinate the world by the end of next year, but their actions show they care more about protecting the monopolies and patents of pharmaceutical giants. A billion vaccine doses would have been a drop in the bucket, but they didn't even manage that. Sharing vaccines will only get us so far - we need all G7 nations to follow the lead of the US, France and over 100 other nations in backing a waiver on intellectual property. By holding vaccine recipes hostage, the virus will continue raging out of control in developing countries and put millions of lives at risk. Prime Minister Johnson and Chancellor Merkel are insisting on defending the monopolies of pharmaceutical companies over people's lives, which is completely inexcusable.

In summary, there is no global division of labor among major stakeholders (states, pharmaceutical companies, global organizations) that would imply any kind of global governance potential now or in the future unless much more effective structures and policies are in place. Whatever you believe, 1 billion doses will not come anywhere near to lessening the current threat of COVID-19, and if the future depends on concerted efforts, the G7 did not reassure.

\section{G7: A CLIMATE OF CHANGE?}

From the preceding quotation, it is clear that many groups were not happy with the outcome of the summit related to climate issues. The question is: What did the G7 agree on, and what did they agree to disagree on? The group agreed to stop international funding for coal projects that lack the technology to capture and store carbon dioxide emissions within the next two years. They promised $\$ 2$ billion to help emerging economies move away from coal-generated power production, as well as committing to "net zero" emissions "no later than 2050." They agreed to raising their contributions to meet the overdue pledge of $\$ 100$ billion a year (only $\$ 80$ million has been raised so far) to help poorer countries cut emissions and cope with climate change, but the financing package for poorer countries and firm financial figures were not placed on the discussion table. Most of this money 
comes in the form of loans, not grants that make it difficult for poor countries to access. The Pakistani Climate Minister, Malik Amin Aslam, reacted this way:

"The G7 announcement on climate finance is really peanuts in the face of an existential catastrophe." He called it a "huge disappointment" for his country and others that have had to spend more to cope with extreme weather, displacement and other impacts of global warming. "At the least, countries responsible for this inescapable crisis need to live up to their stated commitments, otherwise the climate negotiations could well end in futility," he warned (Shear, Friedman, and Einhorn 2021 June 13).

Many energy experts were also expecting a much more ambitious plan, particularly related to the burning of coal since it is the major driver of global warming and putting plans in place for its discontinuation is a priority for the Biden administration. Biden has described climate change as the greatest threat to U.S. national security. The U.K. encouraged other G7 nations to phase out coal by the 2030s to meet their goals of limiting global temperature rise to $1.5 \mathrm{C}$ in accordance with the 2015 Paris Agreement. However, when they all sat down together, they could not agree on a specific time frame to ban coal, and only vaguely agreed to increase efforts to turn away from coal. Agreeing to disagree on a final date for banning coal worried energy experts because it also limits how much pressure can be leveraged against China (the greatest global contributor to carbon emissions) to reign in its own emissions. Jennifer Morgan, executive director of Greenpeace International, told the New York Times: "It's very disappointing. This was a moment when the G7 could have shown historic leadership, and instead they left a massive void" (Shear, Friedman, and Einhorn 2021 June 13). They also failed to commit to new pledges to finance green development projects which many developing countries were hoping for ahead of the UN COP2G climate talks in Glasgow in November.

Immediately after the G7 summit finished, activists from the group Extinction Rebellion staged a demonstration near the summit venue, but most leaders had already left. As one journalist put it: it served to highlight the size of the gap between climate reality and G7 political reality (Herszenhorn 2021 June 13).

\section{THE TAXING GLOBAL FIRMS CHALLENGE}

In the G7 2021 communiqué, leaders asserted that they would "Secure our future prosperity by championing freer, fairer trade within a reformed trading system, a more resilient global economy, and a fairer global tax system that reverses the race to the bottom." It appears there was some kind of consensus and compromise on at least a $15 \%$ minimum global corporate tax (GMT) rate to update international tax laws for a globalized and digital economy. It will be interesting to watch how this initiative will play out with the G20 (including India, China, 
Brazil and Russia) or even in the EU 19, since the 15\% rate is already a compromise and revision down from Biden's 23\% proposal.

Removal of Digital Services Taxes (country-by-country taxes that specifically target the largest American tech companies) adds a level of certainty and more stability to the international tax system that, in the long run, benefits Big Tech companies even if a new Global Minimum Tax raises costs in the short term. This represents a real victory for the United States and Biden's aim to take concrete steps towards what he calls a "foreign policy for the middle class," i.e., supporting globalization and trade that benefit working-class Americans, and not just multinationals and billionaires.

The Organization for Economic Cooperation and Development (OECD) already last fall released a plan for implementation that is based on a two-pillar approach to international taxation. Known as BEPS (Framework on Base Erosion and Profit Sharing), it was negotiated with 137 member countries and jurisdictions. One pillar is for countries to collect taxes from multinational corporations based on the share of that company's profits derived from a particular country's consumers. The second pillar is the global minimum corporate tax, set at a minimum of $15 \%$ that would apply even when tax rates in a particular country are lower than that (Wilkie 2021 June 11). We will need to wait and see if this moves at all forward at the G20 finance ministers and central bank governors meeting in Venice in July where this will be a main topic on the agenda.

\section{CONCLUSION: REFLECTIONS ON THE PRESENT AND FUTURE OF "WESTLESSNESS"}

The annual Munich Security Conference (MSC) report for 2020 stated that a new age of "Westlessness" has emerged, that is, "that the West is in retreat, in decline, and under constant attack - both from within and without." In fact, the pandemic exposed how poorly coordinated and implemented the policies were in Western countries compared to East Asia generally and more specifically to repressive regimes like China. “... the East's success with coronavirus is not a lucky accident. It is the result of a change that has been several decades in the making. Asia had the technology... infrastructure... [and] social trust," write the journalists John Micklethwait and Adrian Wooldridge (2020).

The 2021 MSC report is optimistically entitled "Beyond Westlessness," in response to the hopes incumbent on the new Biden administration and the U.S.'s reentry on the global stage after the traumatic and volatile Trump administration. The journalist Jeremy Cliffe (2021 June 2) asks the question: "Is the world moving 'beyond' Westlessness?" He contends that we are experiencing a transitional moment on two fronts - Western values and Western power. "The West's halfmillennium of pre-eminence is giving way to a new multipolar era in which its 
values are challenged. ... Will the West remain an inclusive, universalist project ... or will it define itself more in exclusionary, civilisation terms? Will the Western alliance outlast Western pre-eminence, or turn out to be a short-lived historical anomaly? How resilient is Western self-confidence and cohesion?"

Are we headed towards a G-0 world as Ian Bremmer (Bremmer and Roubini 2011) envisioned where each nation fights for it's own prescribed self-interests like in Trumps's MAGA-world. Since 2000, the G7's share of global GDP has dropped by $20 \%$ from G5\% to $45 \%$. The threats to Western liberal democracy have increased with tensions rising between Israelis and Palestinians, China and Taiwan, Russia and Ukraine, in Belarus, in Myanmar, etc. At the same time, the quality of democracy is in retrograde in the West and globally. The Economist Intelligence Unit's (2020) Democracy Index says: “Democracy was dealt a major blow in 2020. Almost $70 \%$ of countries covered ... recorded a decline in their overall score, as country after country locked down to protect lives from a novel coronavirus. The global average score fell to its lowest level since the index began in 200G."

Another scenario was coined "Westfullness" and projects that the West will strengthened post-Covid due to investments in and developments of green industries, while China's internal strains combined with Western economic resilience will enable a better global balance of power. A final scenario, called "Westishness" falls between the two previous scenarios. Here:

the West's values and power endure but others fragment. In this future, a more "Eurasian" Europe - drawn towards Asia's growing economic orbit - drifts into a midway position between the US and China. New internal contests to define the West rage: a values-led project or an exclusivist, civilisational one? Global governance evolves into a web of realist forums ... whereby China, the US, India, Russia, Japan and the EU would together thrash out common ground (Cliffe 2021 June 2).

The only certainty is uncertainty and looking at the global forums like the G7 in this article, as well as at the hopes for the Biden administration, the context of uncertainty and propensity for increasing turmoil must be recognized. It is certainly premature to look at "Beyond Westlessness" as a realistic vision of the future and that the further strengthening of democracies and democratization are assured. States, markets and societies need new leadership to become resilient to the outstanding challenges of our times and so we don't fall into the trap of "unknown unknowns." 


\section{REFERENCES}

Al Jazeera (2021 March 19). "As US-Russia ties cool, Putin offers to call Biden". https://www.aljazeera.com/news/2021/3/19/as-us-russia-ties-cool-putinoffers-to-call-biden.

Bremmer, Ian, and Roubini, Nouriel (2011). "A G-Zero World: The New Economic Club Will Produce Conflict, Not Cooperation." Foreign Affairs. March/April.

Cliffe, Jeremy (2021 June 2). "The return of the West: can the G7 nations rebuild a global alliance?" NewStatesman.

https://www.newstatesman.com/world/g7/2021/0G/return-west-can-g7nations-rebuild-global-alliance.

The Economist Intelligence Unit (2020). "Democracy Index 2020: In sickness and in health?" https://www.eiu.com/n/campaigns/democracy-index-2020/. Goodman, Matthew (2021 June 14). "G-7 wants to rival China's Belt and Road plan - but it won't stop Beijing, expert says." CNBC. Politics.

https://www.cnbc.com/2021/0G/14/g-7-infrastructure-plan-wont-stop-chinasbelt-and-road-initiative-csis.html.

G7 Research Group (2021 June 12). "G7 Leaders to Agree Landmark Global Health Declaration." University of Toronto.

http://www.g8.utoronto.ca/summit/2021cornwall/210G12-healthdeclaration.html.

Herszenhorn, David M. (2021 June 13). "5 takeaways from Britain's G7 summit.” Politico. https://www.politico.eu/article/5-takeaways-from-britain-g7summit-cornwall-boris-johnson-coronavirus-china-trade-coal-brexit/.

Klein, Ezra (2021 April 8). "Four Ways of Looking at the Radicalism of Joe Biden." New York Times. https://www.nytimes.com/2021/04/08/opinion/biden-jobsinfrastructure-economy.html.

Lawson, Max (2021 June 13). “Oxfam reaction to G7 Communique.” Reliefweb. World. https://reliefweb.int/report/world/oxfam-reaction-g7-communique. Marcus, Jonathan (17 March 2021). "US-China Relations: Beyond the 'Cold War' cliché." BBC News. https://www.bbc.com/news/world-asia-5G382793.

Micklethwait, John and Wooldridge, Adrian (2020). The Wake-Up Call: Why the Pandemic Has Exposed the Weakness of the West, and How to Fix. London: Short Books Ltd.; New York: HarperCollins Publishers.

Munich Security Conference (2020). Annual Report. Westlessness. https://securityconference.org/assets/user_upload/MunichSecurityReport202 0 .pdf.

Munich Security Conference (2021). Security Brief. Beyond Westlessness. https://securityconference.org/publikationen/munich-security-brief/mscspecial-edition-2021/. 
National Intelligence Council (March 2021). “Global Trends 2040. A More contested World."

https://www.dni.gov/files/ODNI/documents/assessments/GlobalTrends_204 $0 . p d f$.

Shear, Michael D., Friedman, Lisa, and Einhorn, Catrin (2021 June 13). "G7

Nations Take Aggressive Climate Action but Hold Back on Coal." The New York Times.

Wilkie, Christina (2021 June 11). "Biden and G-7 leaders will endorse a global minimum corporate tax of at least 15\%." CNBC. Politics.

https://www.cnbc.com/2021/0G/11/biden-and-g-7-leaders-will-endorse-aglobal-minimum-corporate-tax.html. 